\title{
可視化情報学会全国講演会（関西99）の開催にあたって
}

可視化情報学会会長 小林 敏雄

\section{Message of the President at the Opening of KVS99}

\author{
Toshio KOBAYASHI
}

千年紀を前に1999年の全国講演会が関西大学百周年記念会館で開催の運びとなりました。 今回は、大阪という訪れる機会の多い都市圈で開催されることもあり応募論文数の減少が 心配されましたが、95件の一般講演のお申し込みをいただき、全国大会としては希に見る 多数の講演をいただくこととなりました。内容も多岐にわたる分野における可視化技術の 開発と応用が報告される予定であり、技術の進歩と新しい分野の開拓の息吹を感じますと ともに、可視化情報学会における親交の環のひろがりに感謝します。まさしく活気ある大 阪の地にふさわしい講演会となるのではないかと思われます。講演発表の場、懇親会の場 を通じて個人個人の研究の向上とともに、共有できる研究夕ーゲットの開拓がなされます ことを切望しています。

また、今回は 2 件の特別講演が準備されています。第 1 日目には大阪電気通信大学情報 工学部の小澤一雅先生に「考古学における情報処理とビジュアライゼーション」のご講演 を、第 2 日目には京都工芸繊維大学繊維学部、山岡亮平先生に「アリの社会を化学の目で 観れば」と題してご講演をいただくことになっています。いずれもユニークな内容のお話 が拝聴できるものと、期待が高まります。

さらに、本年の全国講演会では、昨年のCD-ROMによる講演論文集の発行に引き続き、当 学会における論文集オンライン化の最初の試みを行なうこととなりました。論文集をお持 ちの方は、インターネットを介して電子化された論文集を購読できるというシステムであ り、今後の学会からの情報発信形態の重要な一翼を担うものとして注目されております。 ぜひ、紙面での論文集と合わせてご覧いただきたいと思います。

終わりになりましたが、本全国講演会の開催にあたり、ご尽力をいただきました植村知 正委員長（関西大学教授）をはじめとして、奏行委員、幹事、関係各位に厚く御礼申し上 げます。 